\title{
Communication \\ Cheese as a Tourism Resource in Russia: The First Report and Relevance to Sustainability
}

\author{
Vladimir A. Ermolaev ${ }^{1}$, Natalia N. Yashalova ${ }^{2}$ and Dmitry A. Ruban ${ }^{3, *(\mathbb{D}}$ \\ 1 Department of Commodity Science and Expertise, Plekhanov Russian University of Economics, \\ Stremyanny Lane 36, Moscow 117997, Russia; ermolaevvla@rambler.ru \\ 2 Department of Economics and Management, Business School, Cherepovets State University, \\ Sovetskiy Avenue 10, Cherepovets, Vologda Region 162600, Russia; natalij2005@mail.ru \\ 3 K.G. Razumovsky Moscow State University of Technologies and Management (the First Cossack University), \\ Zemlyanoy Val 73, Moscow 109004, Russia \\ * Correspondence: ruban-d@mail.ru
}

Received: 21 September 2019; Accepted: 3 October 2019; Published: 6 October 2019

check for updates

\begin{abstract}
Cheese tasting attracts crowds of visitors to areas in countries such as France, Italy, Spain, and New Zealand, distinguishing cheese tourism as an individual tourism direction within food (gastronomic, culinary) tourism. Internationally known, but locally specific and artisanal cheese is thought to be the main resource. Its exploitation by the tourism industry contributes to sustainability, supporting rural lifestyles and facilitating the integration of rural traditions, heritage, and natural landscapes. In Russia, cheese production is concentrated in regions including Altay, Voronezh, and Moscow. The state of tourist activities favors the use of cheese as a valuable tourism resource. Importantly, this resource is linked to the production of common sorts of cheese in big (industry-scale) amounts and the creation of cheese-related attractions like cheese museums. Cheese festivals also take place locally. A comparison to the European experience of cheese tourism reveals significant peculiarities of this activity in Russia and, particularly, a bigger relevance to industrial tourism than to food and rural tourism. Realization of only part of the opportunities linked to cheese tourism presents challenges regarding environmental and socioeconomical sustainability.
\end{abstract}

Keywords: food industry; regional studies; rural tourism; sustainable development; Altay

\section{Introduction}

Food is an important driver of the tourism industry, and food (gastronomic, culinary) tourism sensu lato has become well established in recent decades. Relevant information is summarized in the works of Cohen and Avieli [1], de Jong and Varley [2], du Rand and Heath [3], Ellis et al. [4], Mak et al. [5], Okumus et al. [6], and Rachão et al. [7]. Much attention has been paid recently to sustainability issues in tourism [8-18]. This broad topic has various aspects, including sustainable tourism growth, tourism's contribution to environmental/socioeconomical sustainability, and tourism industry dependence on local/regional sustainable development.

Importantly, sustainability is worth considering regarding tourism as a whole, as individual types and directions of tourism can gain special importance in a given destination. Food tourism is not exclusive, and its relevance to sustainability issues has become the subject of several studies. De Jong and Varley [19] have demonstrated how food festivals contribute to social sustainability under the influence of such factors as social capital and power relations. Yasmeen [20] has examined long-term societal changes in relation to cuisine as an important tourism resource in India. Zhang et al. [21] have analyzed the relevance of food tourism to sustainable rural development in the Guangdong Province of China, and they have stressed the importance of tourists' perception of the authenticity of local food. 
Food tourism is a vast category. It can be classified depending on cuisine (French, Indian, Russian, etc.), food value chain (restaurant offer, food events, food museums, food production, eating competitions, etc.), and principal product. In each case, its relation to sustainability issues can be traced, but with certain differences. The objective of the present study is to provide the first evidence of cheese as a valuable resource of tourism in some regions of Russia. The relevance of this evidence to sustainable development issues is also discussed.

\section{Literature Review}

Similarly to how apitourism means bee/honey tourism [22] and enotourism means wine tourism [23], cheese tourism can be abbreviated as casetourism-'caseus' is a Latin word meaning 'cheese'. The proposed term is used tentatively in the present study, although only time will tell whether it will be accepted by the international academic community. Cheese tourism seems to be a highly specific activity, but many aspects of it are frequently analyzed. The main findings are systematized below (the advice of literary overview and critical analysis $[24,25]$ has been taken into consideration).

Several specialists define and characterize cheese tourism generally and explain its benefits. Links to food, rural, ethnic, and ecological tourism are emphasized, as well as its strong relevance to various sustainability issues. Ritter [26], who seems to be one of the pioneers of cheese tourism studies, noted artisanal cheese-making as a tourism resource of Bavaria in Germany. Ivic and Protega [27] demonstrated that Pag cheese production has made the island of Pag in Croatia an important destination for gastronomical tourism. Forne [28] coined the term 'cheese tourism' and examined the appearance of this tourism activity in the Vall de Boi in the Catalan Pyrenees of Spain. This is strongly tied to rural tourism through the authentic experience of visitors. The same specialist analyzed cheese tourism in New Zealand [29], and, particularly, the role of farmer's markets in delivering local rural traditions, linking food production to activities in the context of natural landscapes to tourists. Campbell [30] demonstrated how the growth of the Swiss-style cheese-making from yak-cow hybrids increased the local income in Tibet in the mid-20th century, although this practice has been limited because of the strengthened nature conservation initiatives. Folgado-Fernandez et al. [31] discussed the cheese fair experience in the Spanish town of Trujillo. This small event contributes to sustainable tourist destination development and sustains consumption of locally produced food. Wright and Annes [32] paid attention to sheep milk production for Roquefort cheese in Southern France and concluded that women's reflection of rural life is rather diverse and enriches both the local culture and tourist experience. Blanco Murillo [33] analyzed cheese tourism resources in four areas in Costa Rica, Ecuador, Mexico, and Peru. It was concluded that exploitation of these resources activates localized agro-food systems, i.e., cheese tourism can contribute to local food production growth and diversification. This specialist also stresses that the noted resources are not only natural, but are also relevant to the available human capital (know-how approaches, entrepreneurship, etc.). Gibbs et al. [34] analyzed halloumi as a branded product of the Republic of Cyprus. Its involvement in tourism supports its producers via increase in demand and enlarged export opportunities. Ikenaga [35] demonstrated that cheese production by a local agricultural cooperative and its availability at local restaurants supports the alpine pasture management and its relevance to ecotourism in the Austrian Alps. Lozej [36] demonstrated how cheese-making can contribute to sustainable development in the territory of the Triglav national park in Slovenia and, particularly, support effective mountain pasture management. Kruczek and Krauzewicz [37] related cheese offered in one region of Poland to rural tourism and local restaurant offers.

Some other specialists address behavioral aspects of cheese tourism, and, particularly, the preferences of visitors and its effects on them. Alderighi et al. [38] analyzed the importance of some local foods (including the Fontina cheese) of Northern Italy to tourists' intentions. The results are ambivalent. On the one hand, tasting such foods stimulates revisits. On the other hand, this limits interest to only the place of origin. Marcoz et al. [39] paid attention to the same Fontina cheese. Apparently, this is really valued by visitors, but the importance of the protected designation of 
origin certification depends on the distance between the destination and the visitor's home place. Fuste-Forne [40] coined the term 'cheesescapes' and explained their importance to the local sustainable development in the region of Canterbury in New Zealand. This specialist explained that cheese tourism supports and even diversifies activities of local food producers and, at the same time, improves the perception of the local landscapes through the gastronomical experience of visitors. Lenglet and Giannelloni [41] analyzed tourist preferences and perceptions of locally produced cheese. They found that its perceived authenticity is a significant factor in consumers' interest. Ren [42] considered the Oscypek cheese as a tourism resource in one area of Poland to illustrate an interdependence of many actors and activities. For instance, local cheese tourism is linked to sanitary and legislation issues. Importantly, the destination itself changes together with this activity. Torri and Salini [43] examined customer tasting preferences regarding the famous Parmigiano Reggiano cheese at a food exhibit.

A few articles deal with destination branding through cheese tourism. Folgado-Fernandez et al. [44] demonstrated that cheese fairs are important in destination branding. Lizet [45] explained that local cheese production in the Abondance region of the French Alps facilitates place branding and visitor perception.

Finally, some questionable or even negative effects of cheese tourism are explored. Pachoud and Coy [46] addressed a highly specific problem linked to the production of Serrano cheese in the Campos de Cima da Serra region of Brazil and its sale to local visitors. Surprisingly, this tourism-important artisanal activity faces sanitary restrictions, and only the emergence of a local initiative representing the interests of cheese producers is able to resolve the problem. Michna and Rougier [47] found an interesting dilemma regarding cheese production in the Alps. On the one hand, such activities increase the specialization of farmers. On the other hand, they stimulate tourism and protect the original rural state of some areas. Meurs [48] questioned the experience of cultural heritage management in the Zaan region of the Netherlands. Particularly, this specialist noted the launchi of a cheese museum. Commercial exploitation of such tourist attractions by entrepreneurs aimed at profit has challenged conservation of high-value heritage sites. Yonzon and Hunter [49] found that artisanal cheese production (in response to visitor demand) in the Langtang National Park in the Nepal Himalayas led to over-grazing and landscape degradation. These specialists went so far as to recommend restricting cheese production and increasing the price of cheese (they also noted that the price is too high for the locals, whereas foreign visitors would not judge it to be too high). Bava et al. [50] have found that increasing traditional manufacturing of the famous Grana Padano cheese produces considerable environmental effects and contributes to ongoing climate change.

Consideration of the above-mentioned works permits outlining the main peculiarities of cheese tourism, as well as gaps in the relevant knowledge. First, the principal resource of this tourism direction is cheese itself. The majority of the articles focus either on internationally known, but locally specific or artisanal cheese production. However, it appears some regions can be known as important producers of common cheese types in industrial volumes. Undoubtedly, these can also attract the attention of cheese consumers from other regions and countries. Second, casetourism occurs as cheese consumption (via in-situ product buying from local producers-presumably, in shops, farmer's markets, or directly at production sites, via ex-situ tourism-stimulated product exports, and in-situ and ex-situ restaurant offers), cheese-related events (festivals and fairs), and specific attractions like cheese museums. A big question is why excursions to cheese production enterprises are not mentioned. Such excursions would relate cheese tourism to industrial tourism. Third, cheese tourism creates new destinations and contributes to existing destination branding. It is not clear whether cheese tourism attracts all tourists or chiefly Westerners (is cheese valued equally by visitors from, say France, Uruguay, Japan, Congo, and Russia?). Fourth, cheese tourism is a global-scale activity, but it exhibits several loci of concentration. What about its potential in Africa or Southeast Asia? Fifth, the relevance of cheese tourism to sustainability is mentioned very often in the analyzed works. Cheese tourism can be a positive or negative factor of sustainability, depending on the local sustainable development and factors influencing the sustainability of the local tourism industry growth. Two additional, but important 
questions, seem to be unanswered: whether local cheese producers are ready to be involved in tourism activities and whether cheese tourism is related to only mountainous and rural regions. These questions can be formulated more clearly as whether cheese tourism is the only opportunity for local producers to receive an income and whether this activity can increase alone, i.e., in the absence of, other activities such rural, ethnic, and ecological tourism.

Two tentative, explanatory models can be proposed on the basis of the above. The first model characterizes cheese tourism in general (Figure 1). The second model traces the relationship of cheese tourism to both environmental sustainability [51-54] and socioeconomical sustainability [54-56] (Figure 2). First of all, it closely relates cheese production to cheese tourism itself. This pair generates both positive and negative effects. It is possible to find a balance between them via some more general positive consequences, the appearance of extra opportunities, and the facilitation of a proper understanding of local needs. For instance, when a local community (at a place of cheese tourism) obtains a higher quality-of-life expectation due to prosperity, this should facilitate the search for instruments to mediate negative environmental effects, e.g., implementing eco-innovations in agriculture.

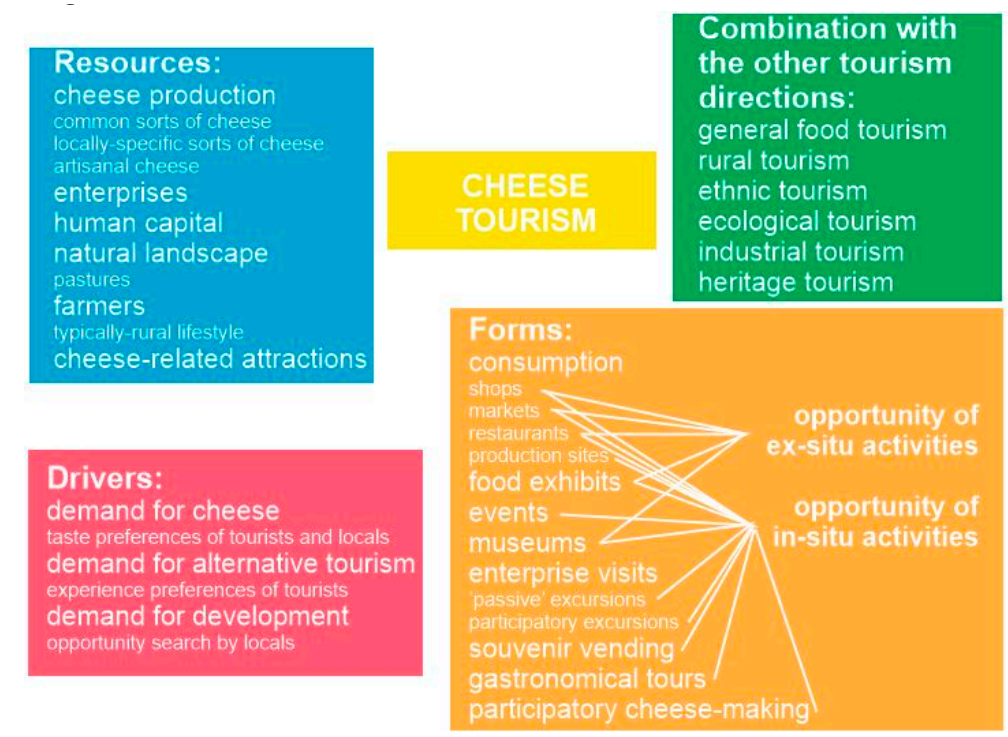

Figure 1. The general essence of cheese tourism.

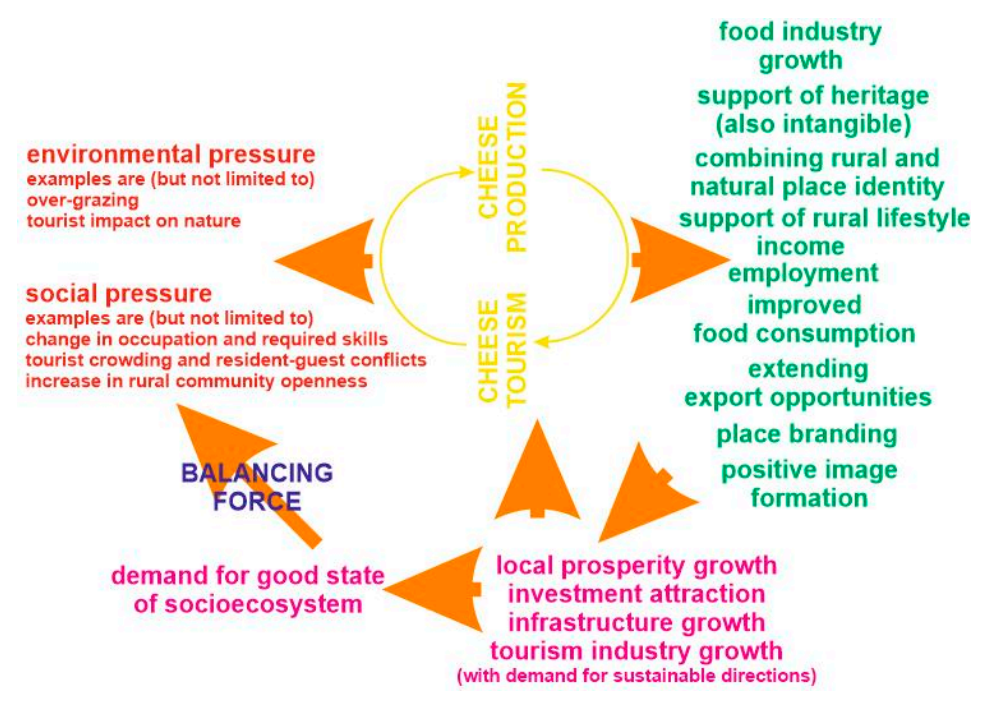

Figure 2. The relevance of cheese tourism to sustainable development. 


\section{Methodology}

Russia is a significant cheese producer, although chiefly for domestic consumption. Thus, cheese tourism can grow there. In order to judge its resources and current state, two types of information are used.

First, officially published statistical information is employed. The main sources of this information include various data provided for free by the Federal Service for State Statistics of the Russian Federation (particularly, its regional database) [57], the Ministry of the Agriculture of the Russian Federation [58], the National Unit of Milk Producers [59], and the Expert-Analytical Centre of Agribusiness [60], as well as two additional, but highly important sources, namely the Agribusiness media-portal [61] and the Gryphon-Expert analytical company [62] (the sources [57-59] contain dispersed data). This information is compiled, compared, and used in a summarized form. Generally, it permits specifying the main regions of cheese production in Russia, describing the dynamics of this production, and characterizing tourist flows to these regions. A comparison of the relative importance of a given region to cheese production and tourism permits general judgments of its potential for cheese tourism.

Second, the information provided on-line (in the Russian segment of the Internet) by cheese producers, tourism firms, local administration, and mass media is later checked in order to confirm cheese tourism activities in the main regions of cheese production. The forms of activities (excursions, festivals, museums, etc.) are specified. The actual and potential impacts are established tentatively. The actual impact marks the spread of cheese-related activities relative to total tourism activities in the region. The potential impact marks the maximum possible contribution of cheese-related activities (i.e., in the case of the full exploitation of the available resource) to regional tourism. Although these judgments are somewhat subjective and qualitative, they are based on the statistical data of tourism development and cheese production (see above). Such judgments seem to be appropriate to compile this pioneering report on this type of food tourism in Russia.

\section{Results}

Cheese is produced in many Russian regions, of which 11 are the most important (Table 1). Enterprises in the Altay and Voronezh regions produce about a quarter of all Russian cheese. In eight regions, cheese production has increased substantially over five years (in the Pskov Region, it rose $>1.5$ times), and a decline took place in only the Republic of Tatarstan (Table 1). The majority of cheese-producing regions are located in the western part of the country, and two regions are situated in Southern Siberia (Figure 3). One should note that the majority of these regions do not boast significant tourist flows (Table 1), and thus, cheese tourism can be an advantage when attracting future visitors. Two territories, namely the Krasnodar Regions coupled with the Republic of Adygeya and the Moscow Region, are more attractive to visitors, and casetourism can contribute to diversification of the available tourism services there. Moreover, it is important that the main cheese-producing regions are located close to important tourist destinations and even coincide with these (Figure 3). Taken together, this evidence implies high cheese tourism potential in some parts of Russia.

Resources of cheese tourism are similar in the main cheese-producing regions. In Russia, cheese is subdivided tentatively into several categories, namely hard and half-hard cheese (typical examples are Swiss, Russian, Soviet, Holland, and Altay sorts), soft cheese (typical examples are Adygeyan, Lyubitel'skiy, and Ostankino sorts), salt cheese (typical examples are Brynza, Stolovyy, and Imeretinskiy sorts), and melted cheese (typical examples are Russian, Soviet, and Ochakovo sorts). These are chiefly common sorts, which are produced in large amounts and without strong geographical attachment. The Altay cheese is a locally specific cheese produced principally in the Altay Region (however, this production is so significant on a national scale that this sort can also be judged as being common), but some other, common sorts are also produced there. Artisanal cheese production is relatively rare and locally restricted. Generally, common sorts of cheese constitute the main resource of casetourism in the Russian regions. In other words, the main attraction is amount, and not specific features of 
cheese production. In the majority of cases, cheese is produced by small and medium enterprises, not by individual farmers. If so, this resource is tied to industrial tourism. The human capital of cheese production differs. Undoubtedly, it is higher in those regions where production is especially voluminous (the Altay, Voronezh, and Moscow regions) and where some artisanal traditions are sustained (the Altay Region and the Udmurt Republic). In other cases, this capital is restricted to the technological knowledge and skills of workers of rather rare enterprises. The natural landscapes (especially pastures) also differ. Typical landscapes of milk-related agriculture can be found in the Altay Region with its 'virgin' mountain pastures. By contrast, the Moscow Region is strongly urbanized, and many other regions are located on forested plains. As noted above, cheese production in Russia is more industry-based than an individual farming initiative. However, a typical rural lifestyle context of cheese production is available, particularly in the Altay, Bryansk, Pskov, and some other regions. Finally, some regions boast cheese-related attractions, namely a cheese village in the Altay Region, cheese museum in the Belgorod Region, and possibilities for participation in artisanal cheese-making in the Altay Region and the Udmurt Republic. The evidence presented above implies that established resources are somewhat restricted in the Russian regions, and these are big only in the Altay Region. There are two specific features of these resources. First, they are strongly related to industrial tourism, although they retain some links to rural tourism. Second, cheese-related attractions are rather common.

The present approaches of exploitation of cheese tourism resources in the Russian regions are summarized in Table 2. Undoubtedly, the most exploited resources can be found in the Altay Region and the Krasnodar Region and the Republic of Adygeya. Excursions to enterprises and events like cheese festivals seem to be quite frequent tourism activities. The majority of cheese-related tourism initiatives are very new and still too restricted (almost occasional), and thus, it is too early to judge their contribution to regional sustainable development. However, these have already started to support economic sustainability via successful regional branding. The latter is especially active in the case of the Altay Region, positioned as a 'core' Russian region of cheese production.

Table 1. Tourism attractiveness of the main cheese-producing regions of Russia (compiled with re-calculations from different sources—see Materials and Methods).

\begin{tabular}{|c|c|c|c|c|c|}
\hline \multirow[b]{2}{*}{ Region } & \multicolumn{3}{|c|}{ Cheese Production } & \multicolumn{2}{|c|}{ Inbound Tourism } \\
\hline & $\begin{array}{l}\text { Production in 2016, } \\
\text { Thousands of Tons }\end{array}$ & $\begin{array}{c}\text { Relatively to } \\
\text { the National } \\
\text { Production, } \\
\% \%\end{array}$ & $\begin{array}{c}\text { Change } \\
\text { Relatively to } \\
2012, \% \%\end{array}$ & $\begin{array}{l}\text { Accommodation in } \\
\text { 2016, Thousands of } \\
\text { Persons }\end{array}$ & $\begin{array}{c}\text { Relatively to the } \\
\text { National } \\
\text { Accommodation, } \\
\% \%\end{array}$ \\
\hline Altay Region & 83.4 & 13.8 & 111 & 611 & 1.1 \\
\hline Voronezh Region & 66.8 & 11.0 & 125 & 601 & 1.1 \\
\hline Bryansk Region & 35.5 & 5.9 & 118 & 182 & 0.3 \\
\hline Omsk Region & 32.7 & 5.4 & 124 & 355 & 0.7 \\
\hline Belgorod Region & 30.5 & 5.0 & $\begin{array}{l}\text { data not } \\
\text { available }\end{array}$ & 199 & 0.4 \\
\hline Pskov Region & 16.6 & 2.7 & 157 & 344 & 0.6 \\
\hline
\end{tabular}

Note: the Krasnodar Region and the Republic of Adygeya are considered as one territory because of their relative geographical position-Adygeya is a small region located inside the large Krasnodar Region. 


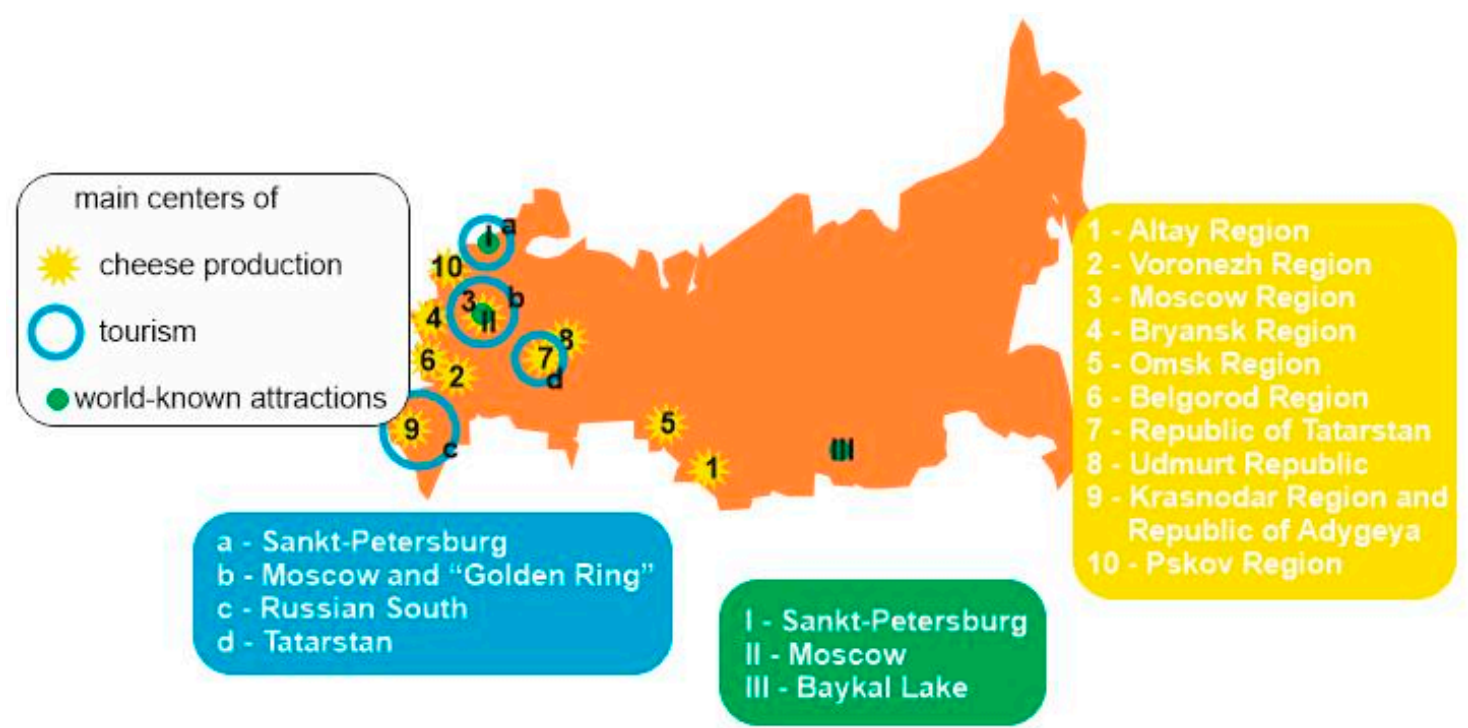

Figure 3. Cheese production in Russia in relation to tourism opportunities.

Table 2. Cheese-related tourism activities in selected regions of Russia (compiled on the basis of various open information available on-line).

\begin{tabular}{|c|c|c|}
\hline Region & Activity & $\begin{array}{l}\text { Actual and Potential Impacts } \\
\text { on Tourism Industry }\end{array}$ \\
\hline Altay Region & $\begin{array}{l}\text { Cheese-based gastronomical tours, festivals, } \\
\text { cheese village attraction, visits to } \\
\text { cheese-producing enterprises, participatory } \\
\text { artisanal cheese-making }\end{array}$ & $\begin{array}{l}\text { Moderate (actual) } \\
\text { High (potential) }\end{array}$ \\
\hline Voronezh Region & Cheese festival & $\begin{array}{c}\text { Minimal (actual) } \\
\text { Moderate (potential) }\end{array}$ \\
\hline $\begin{array}{l}\text { Moscow Region } \\
\text { (except for Moscow city) }\end{array}$ & $\begin{array}{l}\text { Cheese festival, cheese tasting at production } \\
\text { sites, visits to cheese-producing enterprises }\end{array}$ & $\begin{array}{l}\text { Minimal (actual) } \\
\text { Low (potential) }\end{array}$ \\
\hline Bryansk Region & Visits to cheese-producing enterprises & $\begin{array}{l}\text { Minimal (actual) } \\
\text { Low (potential) }\end{array}$ \\
\hline Omsk Region & $\begin{array}{l}\text { Cheese festival, cheese promotion at food } \\
\text { exhibits }\end{array}$ & $\begin{array}{c}\text { Minimal (actual) } \\
\text { Moderate (potential) }\end{array}$ \\
\hline Belgorod Region & Cheese museum & $\begin{array}{l}\text { Low (actual) } \\
\text { Moderate (potential) }\end{array}$ \\
\hline Republic of Tatarstan & Cheese recommended as souvenir & $\begin{array}{l}\text { Minimal (actual) } \\
\text { Low (potential) }\end{array}$ \\
\hline Udmurt Republic & Participatory artisanal cheese-making & $\begin{array}{l}\text { Minimal (actual) } \\
\text { Low (potential) }\end{array}$ \\
\hline $\begin{array}{l}\text { Krasnodar Region and } \\
\text { Republic of Adygeya }\end{array}$ & $\begin{array}{l}\text { Cheese sold as souvenir, cheese festival, } \\
\text { special cheese offer at restaurants, visits to } \\
\text { cheese-producing enterprises }\end{array}$ & $\begin{array}{l}\text { Moderate (actual) } \\
\text { High (potential) }\end{array}$ \\
\hline Pskov Region & $\begin{array}{l}\text { Visits to cheese-producing enterprises, cheese } \\
\text { festival, cheese tasting at production sites }\end{array}$ & $\begin{array}{c}\text { Low (actual) } \\
\text { Moderate (potential) }\end{array}$ \\
\hline
\end{tabular}

\section{Discussion and Conclusions}

The observations in the Russian regions permit extending the vision of cheese tourism in general. Representative examples of cheese tourism from Spain [28,31], Italy [38,39], and New Zealand [29,40] imply it is strongly tied to local and specific food production, as well as to the rural lifestyle. In 
such cases, cheese tourism is based on food consumption and countryside life experience. This also means it is tied to gastronomical and rural tourism. Importantly, cheese tasting takes place both in-situ (at production sites and nearby restaurants) and ex-situ (in restaurants and shops in towns and cities of cheese-producing regions). The situation in Russia seems to be strikingly different. The evidence presented above stresses the importance of excursions to enterprises producing common sorts of cheese. It is natural that in such a situation, consumption itself plays a less important role (common sorts of cheese are available everywhere in the country). If so, casetourism tends to combine with industrial tourism and requires creating more attractions and organizing more events like cheese festivals. In other words, cheese-related activities become more important than cheese itself.

The noted difference between the 'European' and 'Russian' style of cheese tourism can be interpreted in terms of sustainable development. Cheese tourism in the Alps and the Pyrenees contributes to sustainable development via socio-economical support of local rural communities, adding value to local natural heritage, and strengthening links between these communities and heritage (see overview above). The benefits are evident, but it remains questionable how such destinations will react to increasing tourist flows. Remaining rural and possessing significant cultural and natural heritage, they seem to be more vulnerable to crowds of visitors. In the Altay, Moscow, and some other regions of Russia, cheese tourism may contribute to sustainable development via support of enterprises (additional income, branding, increase in demand for production, etc.) and work opportunities for the locals. This contribution may be important, but it will be less harmonious with countryside life. Enterprises opening to visitors and the creation of tourist attractions will stimulate further place modification and authenticity loss. Initial rural essence (when existent) and natural states can start to diminish in response to technical and infrastructure solutions made for tourist needs. Generally, the mode of contribution of cheese tourism to local/regional sustainability depends on the preferred style of this activity, and this contribution should not be considered obvious and necessarily guaranteed. Further investigations of different experiences are required in order to establish criteria for judging sustainable trends. Like many other tourism resources, cheese may or may not offer benefits regarding sustainability. Similar conclusions were made earlier by Meurs [48] and Yonzon and Hunter [49] for Nepal and the Netherlands, respectively.

In conclusion, Russia provides a new and important example of cheese as a tourism resource. The latter is concentrated in 11 regions, of which the Altay, Voronezh, and Moscow regions are the most important. Cheese resources in the noted Russian regions are common sorts of cheese produced by small and medium enterprises, as well as cheese-related tourist attractions. Consideration of the Russian experience permits tracing its relevance to industrial tourism and cheese-related tourist activities, which differs from what is known about cheese tourism in European countries, where cheese tourism is a food tourism direction closely related to rural development. It is also found that although this tourism direction can contribute to sustainability, the relevant activities can also challenge it, and both the contribution and challenges depend on the style of cheese tourism preferred in a given region or country. A lesson from this pioneering analysis of cheese tourism in Russia is that this activity may be very different, and an academic vision restricted to the 'European'-style experience is incomplete. Further investigations should consider the diversity of cheese tourism resources and practices of exploitation available in different parts of the world.

The present investigation of cheese tourism in Russia permits giving several recommendations to potential stakeholders. Farmers involved in cheese production should better communicate with the agro-industrial business community in order to facilitate joint development of rural and industrial activities relevant to cheese tourism (e.g., excursions, festivals, etc.). Large producers of cheese need to consider opening their enterprise for excursions and receiving the support of cheese festivals to stimulate interest from potential tourists (such activities are also important to their branding). The governments of the main cheese-producing regions should think about preparation and successful implementation of special programs/initiatives aimed at cheese tourism promotion (also, as a kind of regional branding) and minimizing their negative effects. In some cases, this can become an efficient 
tool for rural area development. This work raises two questions for regional tourism practitioners. In Russia, available resources of cheese tourism seem to be underexploited. The experience of the Altay Region can be transferred to other cheese-producing regions. The relevance of cheese tourism to sustainability is highly complex. Its practitioners should take into account not only positive, but also numerous negative environmental and socioeconomical effects in order to reach a balance and to make sure their activities contribute to real, not only apparent, sustainability.

Author Contributions: Conceptualization, D.A.R.; methodology, N.N.Y. and D.A.R.; formal analysis, V.A.E. and N.N.Y.; investigation, V.A.E. and D.A.R.; writing, D.A.R.

Funding: This research received no external funding.

Acknowledgments: The authors gratefully thank the journal editor and the three, anonymous reviewers for their helpful suggestions, as well as some colleagues for discussion of cheese production in Russia.

Conflicts of Interest: The authors declare no conflict of interest.

\section{References}

1. Cohen, E.; Avieli, N. Food in tourism-Attraction and impediment. Ann. Tour. Res. 2004, 31, 755-778. [CrossRef]

2. De Jong, A.; Varley, P. Food tourism policy: Deconstructing boundaries of taste and class. Tour. Manag. 2017, 60, 212-222. [CrossRef]

3. Du Rand, G.E.; Heath, E. Towards a framework for food tourism as an element of destination marketing. Curr. Issues Tour. 2006, 9, 206-234.

4. Ellis, A.; Park, E.; Kim, S.; Yeoman, I. What is food tourism? Tour. Manag. 2018, 68, 250-263. [CrossRef]

5. Mak, A.H.N.; Lumbers, M.; Eves, A. Globalisation and food consumption in tourism. Ann. Tour. Res. 2012, 39, 171-196. [CrossRef]

6. Okumus, B.; Koseoglu, M.A.; Ma, F. Food and gastronomy research in tourism and hospitality: A bibliometric analysis. Int. J. Hosp. Manag. 2018, 73, 64-74. [CrossRef]

7. Rachão, S.; Breda, Z.; Fernandes, C.; Joukes, V. Food tourism and regional development: A systematic literature review. Eur. J. Tour. Res. 2019, 21, 33-49.

8. Buckley, R. Sustainable tourism: Research and reality. Ann. Tour. Res. 2012, 39, 528-546. [CrossRef]

9. Butler, R.W. Tourism, Environment, and Sustainable Development. Environ. Conserv. 1991, 18, $201-209$. [CrossRef]

10. Butler, R.W. Sustainable tourism: A state-of-the-art review. Tour. Geogr. 1999, 1, 7-25. [CrossRef]

11. Cater, E. Ecotourism in the third world: Problems for sustainable tourism development. Tour. Manag. 1993, 14, 85-90. [CrossRef]

12. Clarke, J. A framework of approaches to sustainable tourism. J. Sustain. Tour. 1997, 5, 224-233. [CrossRef]

13. Estêvão, R.S.G.; Ferreira, F.A.F.; Rosa, Á.A.; Govindan, K.; Meidutè-Kavaliauskienè, I. A socio-technical approach to the assessment of sustainable tourism: Adding value with a comprehensive process-oriented framework. J. Clean. Prod. 2019, 236, 117487. [CrossRef]

14. Hall, C.M. Constructing sustainable tourism development: The 2030 agenda and the managerial ecology of sustainable tourism. J. Sustain. Tour. 2019, 27, 1044-1060. [CrossRef]

15. Hunter, C. Sustainable tourism as an adaptive paradigm. Ann. Tour. Res. 1997, 24, 850-867. [CrossRef]

16. Panzer-Krause, S. Networking towards sustainable tourism: Innovations between green growth and degrowth strategies. Reg. Stud. 2019, 53, 927-938. [CrossRef]

17. Sharpley, R. Tourism and sustainable development: Exploring the theoretical divide. J. Sustain. Tour. 2000, 8 , 1-19. [CrossRef]

18. Yoopetch, C.; Nimsai, S. Science mapping the knowledge base on sustainable tourism development, 1990-2018. Sustainability 2019, 11, 3631. [CrossRef]

19. De Jong, A.; Varley, P. Food tourism and events as tools for social sustainability? J. Place Manag. Dev. 2018, 11, 277-295. [CrossRef]

20. Yasmeen, N. Sustainable food tourism: Travelers, tourists, migrants and their food habits-Indian perspective. Int. J. Hosp. Tour. Syst. 2019, 12, 94-102.

21. Zhang, T.; Chen, J.; Hu, B. Authenticity, quality, and loyalty: Local food and sustainable tourism experience. Sustainability 2019, 11, 3437. [CrossRef] 
22. Pantoja, G.; Gómez, M.; Contreras, C.; Grimau, L.; Montenegro, G. Determination of suitable zones for apitourism using multi-criteria evaluation in geographic information systems: A case study in the $\mathrm{O}^{\prime}$ Higgins Region, Chile. Cienc. Investig. Agrar. 2017, 44, 139-153. [CrossRef]

23. Winfree, J.; McIntosh, C.; Nadreau, T. An economic model of wineries and enotourism. Wine Econ. Policy 2018, 7, 88-93. [CrossRef]

24. Fernandez, K.V. Critically reviewing literature: A tutorial for new researchers. Australas. Mark. J. 2019, 27, 187-196. [CrossRef]

25. Snyder, H. Literature review as a research methodology: An overview and guidelines. J. Bus. Res. 2019, 104, 333-339. [CrossRef]

26. Ritter, W. Craft-industry formations in northern Bavaria. Ber. Dtsch. Landeskd. 1987, 61, 425-451.

27. Ivic, P.; Protega, I. The island of Pag and its culinary riches. Adv. Bus. Relat. Sci. Res. J. 2018, 9, 43-49.

28. Forne, F.F. Cheese tourism in a world heritage site: Vall de Boi (Catalan Pyrenees). Eur. J. Tour. Res. 2015, 11, 87-101.

29. Forne, F.F. Local cheese in farmers' markets: Community and tourism development in Canterbury, New Zealand. E Rev. Tour. Res. 2015, 12, 281-289.

30. Campbell, B. Biodiversity, livelihoods and struggles over sustainability in Nepal. Landsc. Res. 2018, 43, 1056-1067. [CrossRef]

31. Folgado-Fernandez, J.A.; Di-Clemente, E.; Hernandez-Mogollon, J.M. Food festivals and the development of sustainable destinations. The case of the cheese fair in Trujillo (Spain). Sustainability 2019, 11, 2922. [CrossRef]

32. Wright, W.; Annes, A. Farm Women and Agritourism: Representing a New Rurality. Sociol. Rural. 2014, 54, 477-499. [CrossRef]

33. Blanco Murillo, M. SIAL activation via the farmhouse: Analysis of the interaction potential in four cheese of Latin America territories. Agroalimentaria 2012, 18, 123-131.

34. Gibbs, P.; Morphitou, R.; Savva, G. Halloumi: Exporting to retain traditional food products. Br. Food J. 2004, 106, 569-576. [CrossRef]

35. Ikenaga, M. The transition of alpine pasture management and the development of ecotourism in Hinterhornbach village, Tyrol, in the Austrian Alps. Jpn. J. Hum. Geogr. 2001, 53, 48-65. [CrossRef]

36. Lozej, S.L. Grazing and dairying in the mountain pastures of triglav national park: Cultural heritage and current questions. Traditiones 2013, 42, 49-68. [CrossRef]

37. Kruczek, Z.; Krauzewicz, M. Turystyka kulinaria na Podhalu. Tur. Rekreac. 2016, 2, 17-33.

38. Alderighi, M.; Bianchi, C.; Lorenzini, E. The impact of local food specialities on the decision to (re)visit a tourist destination: Market-expanding or business-stealing? Tour. Manag. 2016, 57, 323-333. [CrossRef]

39. Marcoz, E.M.; Melewar, T.C.; Dennis, C. The Value of Region of Origin, Producer and Protected Designation of Origin Label for Visitors and Locals: The Case of Fontina Cheese in Italy. Int. J. Tour. Res. 2016, 18, $236-250$. [CrossRef]

40. Fuste-Forne, F. Tasting cheesescapes in Canterbury (New Zealand). N. Z. Geogr. 2016, 72, 41-50. [CrossRef]

41. Lenglet, F.; Giannelloni, J.-L. Does a Terroir Product Tell the Same Story to Tourists, Day-trippers and Local Consumers? The Moderating Role of Variety-seeking Tendency and Perceived Authenticity. Int. J. Tour. Res. 2016, 18, 494-505. [CrossRef]

42. Ren, C. Non-human agency, radical ontology and tourism realities. Ann. Tour. Res. 2011, 38, 858-881. [CrossRef]

43. Torri, L.; Salini, S. An itinerant sensory approach to investigate consumers' perception and acceptability at a food exhibition. Food Res. Int. 2016, 90, 91-99. [CrossRef]

44. Folgado-Fernandez, J.A.; Hernandez-Mogollon, J.M.; Duarte, P. Destination image and loyalty development: The impact of tourists' food experiences at gastronomic events. Scand. J. Hosp. Tour. 2017, 17, 92-110. [CrossRef]

45. Lizet, B. The 'genie' of the alpine pastures. Landscape, cows and cheese in the Abondance region of the French Alps. Rev. Geogr. Alp. 1998, 86, 35-50. [CrossRef]

46. Pachoud, C.; Coy, M. Relations of proximity between local actors and territorial development dynamics: Analysis of the queijo artesanal serrano value chain in the Campos de Cima da Serra Region/RS. Rev. Bras. Gestao Desenvolv. Reg. 2018, 14, 157-182.

47. Michna, R.; Rougier, H. Rural regions in the French Alps: Development between decline and modernisation. Geogr. Rundsch. 2013, 65, 34-39. 
48. Meurs, P. Fifty years zaanse schans: A reservation of monuments that was never intended as an open air museum. KNOB Bull. 2013, 112, 185-203.

49. Yonzon, P.B.; Hunter, M.L. Cheese, Tourists, and Red Pandas in the Nepal Himalayas. Conserv. Biol. 1991, 5, 196-202. [CrossRef]

50. Bava, L.; Bacenetti, J.; Gislon, G.; Pellegrino, L.; D’Incecco, P.; Sandrucci, A.; Tamburini, A.; Fiala, M.; Zucali, M. Impact assessment of traditional food manufacturing: The case of Grana Padano cheese. Sci. Total Environ. 2018, 626, 1200-1209. [CrossRef]

51. Goodland, R. The concept of environmental sustainability. Annu. Rev. Ecol. Syst. 1995, 26, 1-24. [CrossRef]

52. Gupta, K. Environmental sustainability and implied cost of equity: International evidence. J. Bus. Ethics 2018, 147, 343-365. [CrossRef]

53. Kemp, R. Technology and the transition to environmental sustainability. The problem of technological regime shifts. Futures 1994, 26, 1023-1046. [CrossRef]

54. Starik, M.; Stubbs, W.; Benn, S. Synthesising environmental and socio-economic sustainability models: A multi-level approach for advancing integrated sustainability research and practice. Australas. J. Environ. Manag. 2016, 23, 402-425. [CrossRef]

55. Iribarren, D.; Martín-Gamboa, M.; O’Mahony, T.; Dufour, J. Screening of socio-economic indicators for sustainability assessment: A combined life cycle assessment and data envelopment analysis approach. Int. J. Life Cycle Assess. 2016, 21, 202-214. [CrossRef]

56. Karppi, I.; Kultalahti, O.; Kultalahti, J. On socio-economic sustainability and robustness. Eur. Spat. Res. Policy 2012, 19, 5-7. [CrossRef]

57. Federal Service for State Statistics of the Russian Federation. Available online: gks.ru (accessed on 29 August 2019).

58. Ministry of the Agriculture of the Russian Federation. Available online: mcx.ru/ (accessed on 29 August 2019).

59. National Unit of Milk Producers. Available online: http://souzmoloko.ru/ (accessed on 29 August 2019).

60. Expert-Analytical Centre of Agribusiness. Available online: ab-centre.ru (accessed on 29 August 2019).

61. Agribusiness. Available online: http://www.agbz.ru/news/top-20-subyektov-rossii-po-obyemamproizvodstva-syirov-i-syirnyih-produktov (accessed on 29 August 2019).

62. Gryphon-Expert. Available online: http://grifon-expert.ru/obzory/111-obem-i-dinamika-proizvodstva-ipotrebleniya-syrov-i-syrnyh-produktov-v-rf-2010-2017.html (accessed on 29 August 2019).

(C) 2019 by the authors. Licensee MDPI, Basel, Switzerland. This article is an open access article distributed under the terms and conditions of the Creative Commons Attribution (CC BY) license (http://creativecommons.org/licenses/by/4.0/). 